\title{
The Needs and Possibilities of Application of Management Accounting and Controlling Tools Which Support Risk Identification and Assessment in Successive Phases of Company Growth
}

\begin{abstract}
Adriana Kaszuba-Perz*
In this paper, selected research areas related to risk management processes in the subsequent phases of the development of small and medium-sized enterprises are discussed. It seems on the surface that this particular group of companies has a weak interest in tools that could improve decision-making. But entrepreneurship, which is a feature of small businesses, is manifested, among others, by flexible operation and willingness to take risks. Attempts to describe risk and its scale (mostly qualitatively) are taken in varying degrees by the entrepreneur and by managers in the later stages of development of the company. Therefore, it seems reasonable to analyze this phenomenon comprehensively and in a multi-dimensional way in the growth process of the company. This article is just a part of a deeper analysis in the framework of research in this area.
\end{abstract}

Keywords: enterprise growth processes, controlling management, risk management.

Submitted: 22.08.2016 | Accepted: 19.10.2016

\section{Potrzeby i możliwości zastosowania narzędzi rachunkowości zarządczej i controllingu, wspomagających identyfikację i ocenę ryzyka w procesie wzrostu przedsiębiorstwa}

W opracowaniu zaprezentowano wybrane obszary badawcze odnoszace się procesów zarzadzania ryzykiem $w$ kolejnych fazach rozwoju matego i średniego przedsiębiorstwa. Wydaje się z pozoru, że ta szczególna grupa przedsiębiorstw wykazuje stabe zainteresowanie metodami, które moglyby usprawniać podejmowanie decyzji. Przedsiębiorczość, która jest cecha matych przedsiębiorstw przejawia się jednak przecież m.in. poprzez elastyczne działanie i skłonność do podejmowania ryzyka. Próby opisu (głównie jakościowe) ryzyka i jego skali podejmowane sa $w$ różnym stopniu przez samego przedsiębiorce oraz $w$ późniejszych fazach rozwoju przedsiębiorstwa przez menedżerów. Wobec czego uzasadnione wydaje się wszechstronne $i$ wielowymiarowe analizowanie tego zjawiska $w$ procesie wzrostu przedsiębiorstwa. Opracowanie jest fragmentem gtębszej analizy $w$ ramach prowadzonych badań $w$ tym zakresie.

\footnotetext{
Adriana Kaszuba-Perz - PhD, Department of Finance, Banking and Accounting, Faculty of Management, Rzeszow University of Technology.

Mailing address: Department of Finance, Banking and Accounting, Faculty of Management, Rzeszow University of Technology, al. Powstańców Warszawy 10, 35-959 Rzeszów; e-mail: aperz@prz.edu.pl. 
Słowa kluczowe: procesy wzrostu przedsiębiorstwa, zarządzanie controllingowe, zarządzanie ryzykiem.

Nadesłany: 22.08.2016 | Zaakceptowany do druku: 19.10.2016

JEL: M41

\section{Introduction}

Variability of the enterprise environment, volatility and complexity of its internal processes and phenomena characterizing modern economy (i.e. globalization and high competition, the development of technology, especially information one) contribute to the growing importance of tools supporting risk identification and measurement as one of the company management areas. The experiences of companies worldwide, but also analyses conducted by Polish researchers (i.a. Kasiewicz, 2011; Nowak, 2010), show that the skills of effective risk management in a company have been and will become increasingly important in the context of its further development and survival on the market. Taking into account that in the economic life of countries and regions a significant role is still played by small and medium-sized enterprises competing with large corporations of an international character (see i.a. Koźmiński, 2004; Kochmańska, 2007; Bober and Chęciński, 2012, and also: Borowiecki and Siuta-Tokarska, 2008), the risk of their operations will affect more and newer areas and it will deepen. Therefore, it seems reasonable to study and analyze the risks involved in the development of these particular entities in subsequent phases of their growth.

The aim of this article is to present the possibilities of application of risk management tools in the subsequent phases of the growth of small and medium-sized enterprises ${ }^{1}$. This issue seems interesting, among others, due to the following facts:

1. enterprises shifting into the next stages of development "experience" breakthroughs, which may be especially risky;

2. small and medium-sized enterprises are considered to be highly flexible, but the risk or some of the factors that cause it may be underestimated by the entrepreneurs themselves;

3. possibilities of identification, measurement and management of risk vary with age and size of the company.
Because of multithreading and breadth of the subject matter, this article is only a part of a deeper study on ongoing research in this area.

\section{Growth Processes of Small- and Medium-Sized Enterprises (SMEs) in the Context of Information and Risk Management}

The issue of company growth and life cycle is widely discussed in the literature, hence there are many models of development processes of organizations and companies (see i.a. Matejun and Motyka, 2015; Sysko-Romańczuk, 2005; Sysko-Romańczuk and Lozano Platonoff, 2003). Among the most popular there is the one built by Robert E. Quinn and K. Cameron, which was created on the basis of the sum of nine other models (Quinn and Cameron, 1983). They assume that the process of company development follows four stages: entrepreneurial, collectivity, formalization and control, and the last - transformation. An important concept from the point of view of this study is also that developed by I. Adizes (Adizes, 1988), which assumes the coexistence of four core areas that are the source of enterprise development, namely: the production area, the area of administration (management, i.e. the creation of a formal order in terms of structures and processes), the area of entrepreneurship associated with creating a change and an implementation of innovation, and integration manifested through interaction of "organization participants" (more see: Kozień, 1999, p. 136). This idea seems interesting, especially when it comes to linking the issues of the growth process of the company and the role of entrepreneurship - understood as a feature of the people setting up the organization.

The starting point for this analysis is a five-step process of growth of small businesses. The concept is described by N.C. Churchill and V.L. Levis (Churchill and Levis, 1983). Organizational structures, 


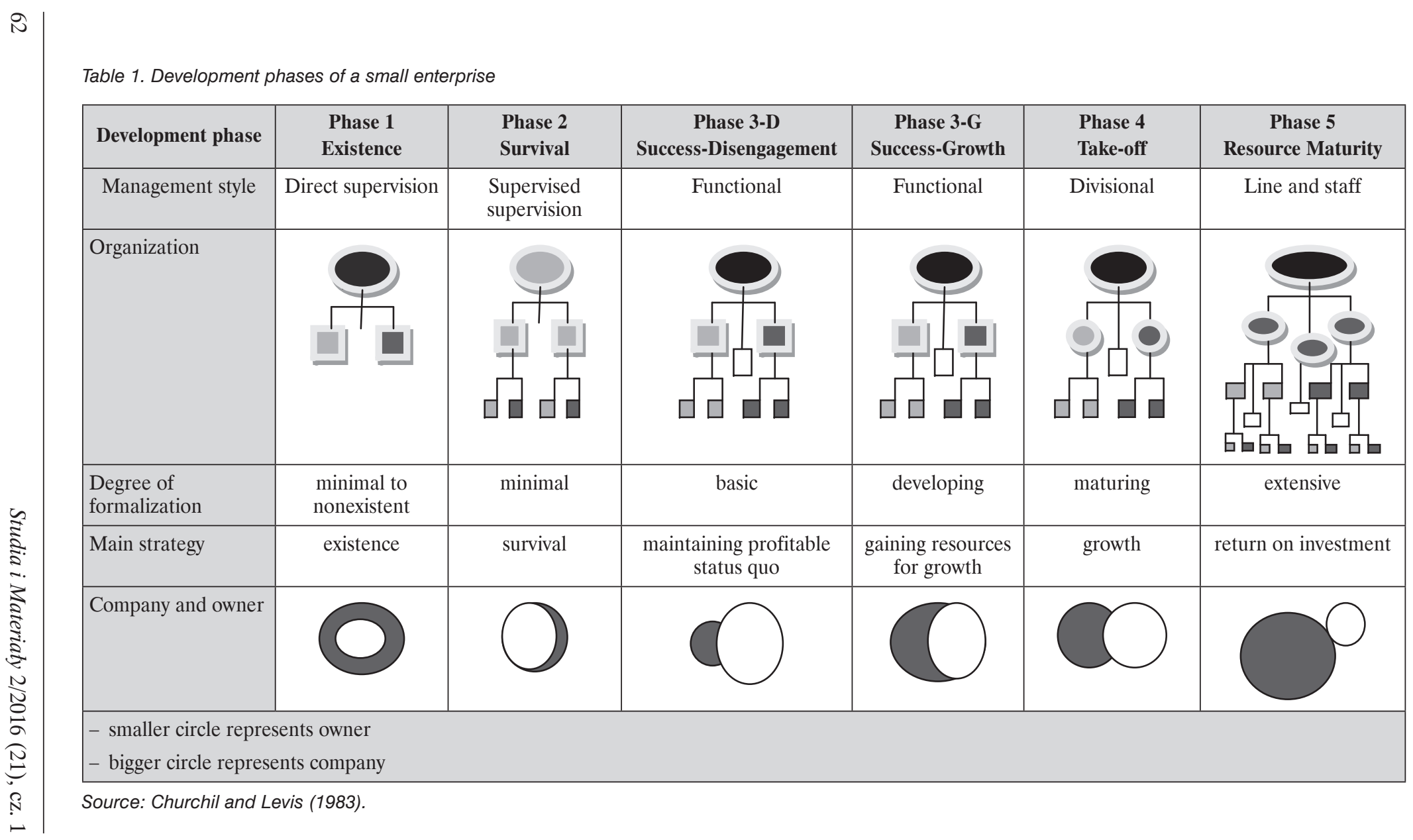


management style, strategy and role of the entrepreneur in small and medium-sized enterprises are adjusted to the phase in the development cycle of such an enterprise. During the first stage, the company is mostly a one-man business (according to the definition adopted - a micro-enterprise). At the later stages an entrepreneur is obliged to coordinate the work of other people and delegate some decisions to lower levels. In phase 3 , the organizational structure is more complex, the strategy and role of the entrepreneur change. In subsequent stages these changes deepen, and the entrepreneur - the owner - supports the professional managerial staff. A detailed description of the various phases is illustrated in Table 1.

In this concept, what is inspiring is not only thorough characteristics of different phases of company development but also the breakthroughs leading to the various stages. This seems to matter from the point of view of the subject of this study as exactly these special moments in the life of the company - strategic decisions related to the further development of the company - undoubtedly carry the highest risk. The breakthrough is considered as the moment at which, due to internal or external factors, there are changes (one-off or continuous) causing long-term effects, and even destabilizing the existing balance of the organization (Roth and Kurtyka, 2008, p. 147). The factors that cause strategic breakthroughs in an enterprise were characterized by Olszewska (Olszewska, 2010, pp. 130-136). An example of a model of development of the organization which also takes into account a "revolutionary change" causing the end of the growth stage of the organization is presented by L.E. Greiner, who distinguishes five characteristic stages of growth (Gościński, 1989, pp. 23-26). These "revolutionary changes", breakthroughs in the life cycle of the company, at times bring about a high level of risk. Unfortunately, Polish entrepreneurs rarely make attempts to investigate it, and they rely solely on their intuition and experience. The concept of the use of any controlling tools to evaluate their undertakings, including the risks associated with them, emerges only after success before the development phase. Professional tools for identification, measurement and overcoming the effects of risk are used only in large mature companies.

\section{The Risk Concept, Classifications and the Need for Its Management in Small and Medium-Sized Enterprises}

Risk is an inherent part of life of any organization. It also seems that it plays a huge role especially at groundbreaking moments, and then its recognition, measurement and finding ways to avoid its negative effects is vital for the survival of the company. This article discusses the risk issues in the context of the life cycle of the company and at this point it is necessary to refer to its definition. Risk is generally regarded as a fairly capacious concept, hence there are a lot of definitions and classifications of risk (i.a. Chapman, 2011; Hopkin, 2012; Jajuga, 2008; Varvari, 2015).

It should be noted that this concept is often associated with uncertainty. Referring to the classics, it is worth quoting the theory proposed by F. Knight, where there are two types of uncertainty: of the immeasurable nature, and the one that can be parameterized and is measurable - thus it can be defined as risk (Knight, 1921, p. 94).

When defining uncertainty, Koźmiński indicates a lack of information about future events, which impedes decision (Koźmiński, 2012, p. 20). On the other hand, W. Grzybowski indicates that actions that are taken in conditions of uncertainty for its minimization or exclusion are highly entrepreneurial (Grzybowski, 1995, p. 19). This approach is closely related to the theory of growth of small and medium-sized enterprises, whose activity is tied to entrepreneurship and willingness to take risks.

According L. Pasieczny, risk is defined as a situation in which "at least one of the elements making it up is unknown" (Pasieczny, 1981). Generally, among researchers studying the concepts of risk and uncertainty, consensus is noticeable. We are talking about risk when the results of its occurrence are identifiable on the basis of probability, and in the case of uncertainty - the results are not known for a given situation (Knight, 2005; Wierzbińska, 1996). What is also worth quoting is the definition by T. Kaczmarek that, from the point of view of the subject, seems to be extremely important - risk is considered as a failure independent of the entity which cannot be previously predicted and whose effects cause a reduction in performance or gen- 
eral lack of effectiveness in operation (Kaczmarek, 1999).

The main factors influencing the analyzed literature typology of risks are risk sources, structure and tools for its measurement ${ }^{2}$. The most commonly used criteria for the distribution of risk are its range (Rogowski and Michalczewski, 2005, p. 24) and subjective scope (Ostrowska, 2002, pp. 43-44). In the first case, one talks about systematic risk, whose source is external environment, and the entity does not affect it, and unsystematic risk - the internal one, which can be controlled by the organization. On the other hand, according to subjective criteria there are: business risk (for all areas of risk), projects (realized by the company in the context of its development), risk of owners, risk of the sector. An interesting description of risks by category and source is also offered by M. Thlon. Based on this classification one can try to identify potential risks in the different phases of the life cycle of enterprises (see: Table 2).

Table 2. Categories and sources of risk in the context of the phases of growth of the company

\begin{tabular}{|c|c|c|}
\hline Risk category & Exemplary risk sources & $\begin{array}{l}\text { Possibility of occurrence at various stages } \\
\text { of company life cycle* }\end{array}$ \\
\hline $\begin{array}{l}\text { External } \\
\text { unpredictable } \\
\text { risk }\end{array}$ & $\begin{array}{l}\text { - Unexpected changes in regulations } \\
\text { - Fire, natural disasters } \\
\text { - Sabotage, vandalism } \\
\text { - Social unrest, riots } \\
\text { - Unforeseen financial crisis }\end{array}$ & $\begin{array}{l}\text { The risk occurring continuously regardless } \\
\text { of the stage of growth of the company. }\end{array}$ \\
\hline $\begin{array}{l}\text { External } \\
\text { predictable } \\
\text { risk }\end{array}$ & $\begin{array}{l}\text { - Changes in the financial markets } \\
\text { - Inflation, tax regulations } \\
\text { - Security } \\
\text { - The demand for commodities, the } \\
\text { value of the product or service }\end{array}$ & $\begin{array}{l}\text { The risk occurring continuously regardless } \\
\text { of the stage of growth of the company. }\end{array}$ \\
\hline $\begin{array}{l}\text { Internal } \\
\text { non-technical } \\
\text { risk }\end{array}$ & $\begin{array}{l}\text { - Management changes } \\
\text { - Poor coordination of human } \\
\text { resources } \\
\text { - Cash flow disturbance } \\
\text { - Errors of employees } \\
\text { - Access restrictions } \\
\text { - Late deliveries }\end{array}$ & $\begin{array}{l}\text { The risk occurring continuously, but } \\
\text { can occur with increased force in the } \\
\text { breakthrough times. The first two factors (i.e. } \\
\text { management changes and poor coordination } \\
\text { of human resources) will be particularly } \\
\text { important in the transition and emergence of } \\
\text { new organizational structures, among others, } \\
\text { between phase } 2 \text { and } 3 \text {, and } 3 \text { and } 4 \text {. }\end{array}$ \\
\hline $\begin{array}{l}\text { Technical } \\
\text { risk }\end{array}$ & $\begin{array}{l}\text { - Technological changes } \\
\text { - Changes in quality requirements } \\
\text { - Capacity limitation } \\
\text { - Changes in demand } \\
\text { - Incorrect implementation of the } \\
\text { product }\end{array}$ & $\begin{array}{l}\text { Continuous risk. It should be stressed that } \\
\text { technological change and productivity } \\
\text { reduction will be key in steps } 3 \text { and } 4 \text {. }\end{array}$ \\
\hline Legal risk & $\begin{array}{l}\text { - Licensing issues, protection of } \\
\text { copyrights and patents } \\
\text { - Lawsuits from customers } \\
\text { - Lawsuits from employees } \\
\text { - Failed contracts } \\
\text { - Operation of market regulators }\end{array}$ & Continuous risk. \\
\hline
\end{tabular}

* Determination of phases in the life cycle of the company based on the concept by N.C. Churchill and V. L. Levis described in this article.

Source: study based upon: Thlon (2013, p. 30). 


\section{Information and Risk Management and Controlling Tools in Subsequent Phases of a Developing Business}

As already mentioned in the introduction, important factors affecting the business, especially the development processes of enterprises, are: development of international corporations, intensified competition, information technology. These processes often necessitate the use of new practices in the organization and management tools for an in-depth analysis of the environment and risks occurring there 3 . Information obtained through the use of appropriate management tools (especially controlling tools) supports a process of continuous comparison of current activities and results with the outcomes and the objectives set out in the strategy. The results of such comparisons become an effective tool to identify threats by detecting deviations from the approved plans, especially finding and analyzing the causes of these deviations. One of the most important goals of a modern enterprise is to maximize the market value - it takes on particular significance in the phases of development and maturity. Procedures and risk management tools undoubtedly have a direct impact on the value of the company, which results in including them in an overall controlling management system (more on this subject: Kaszuba-Perz and Perz, 2008, 2010). The fact of a positive impact of effective risk management on the competitive position of the company seems obvious. But it is still treated as an integral part of the business and especially the development of enterprises. As mentioned earlier, the impact of the factors causing risk is even stronger during transition to the next phase of development of the economic entity. A. Damodaran lists several common characteristics of companies that gain a competitive advantage through risk-taking. They are (Damodaran, 2009, pp. 423-424):

- Consensus of interests of managers and owners of the company;

- Selection of the right risk management executives and decision-makers;

- Implemented incentive system - compatible with processes to eliminate bad decisions and risk;

- Organizational culture and structure of the company to support risk management processes.
These features seem to be characteristic of companies that have already been successful (phase 3) and proceed to the development phase and further to maturity. As then there is the separation of management functions, transfer of decision-making powers to lower levels of management, formation of a new organizational structure adapted to the size of the company and its strategy, or even implementation of new management systems in the individual business areas. The risk - which in this case may appear to be well diagnosed and evaluated - becomes the driving force behind the development and struggle in a competitive market. However, keeping in mind that these are micro and small enterprises, where decisions are often taken intuitively by the owner, they are generally considered as highly-flexible and willing to risk. So one can venture to say that at every stage of company growth, the tendency will to a large extent depend on the abilities, skills and knowledge of owners and managers. Certainly it is much easier to make a decision based on the diagnosed risk factors, and to know the degree of their impact on our enterprise. However, the scale of the projects undertaken (decision) is different at the stage of survival and at the stage of development and maturity. Personal qualities and qualifications of the ownerentrepreneur or management staff are the factors that undoubtedly affect the way of gathering data for management purposes, including the analysis of risks. This applies both to organizing the sources of information (e.g. financial and accounting system) and the channels of flow and processing thereof. Undoubtedly, the most important factors in the processes of risk management include the quantity and quality of information. These change with the growth of the company and also depend on qualifications of the management or development of internal channels of distribution. The nature of information depends also on the management level (as shown in Table 1), and one needs to remember that the management style and management tools will change in subsequent phases of the life of the company. With the development of the enterprise, internal and external information flow channels are evolving within the company. This may result in a continuous improvement of the information database and distribution channels necessary to ana- 
Table 3. Information type vs. management level

\begin{tabular}{|c|c|c|}
\hline \multirow{2}{*}{ Information features } & \multicolumn{2}{|c|}{ Management level } \\
\hline & Higher & Lower \\
\hline Kind of decision & Strategic & Operational \\
\hline Character of decision & Non-structured & Structured \\
\hline Information purpose & Objectives formulation & Current activity \\
\hline Time horizon & Long period & Short period \\
\hline Uncertainty level & High & Low \\
\hline Aggregation level & High & Low \\
\hline Frequency of gathering and application & Little & Big \\
\hline Source of information & External & Internal \\
\hline
\end{tabular}

Source: Cebrowska (2010, p. 559).

lyze processes and decision-making or, on the contrary, in disruptions in the flow of data. For this reason, it seems important to build an information management system where information would be properly classified and assigned to the levels of management. A general model of such a classification of information for management purposes was described by T. Cebrowska (see Table 3).

It should be noted that in a developing enterprise, in the individual phases of its growth, the type of information can be assigned to one of two levels of management (according to Table 3 ). It is connected with the changing role of the entrepreneurowner as well as the evolving organizational structure and shaping the organizational culture of the company. The above-mentioned features of a developing business influence the quality and type of information and thus the possibility of using some tools to support decision-making processes in the enterprise (see Table 4).

The use of modern tools of controlling and management accounting is a manifestation of entrepreneurship, innovation and the desire to gain a competitive advantage in terms of a broader analysis of the situation of the company. However, the degree and extent of use of these tools is determined by several factors. To define the role of management accounting and controlling in business management and its effectiveness, A. Szychta lists i.a.: factors imposed by legislation and transnational agree- ments (including those regarding the harmonization of the regulation of financial accounting), the decisions of multinational companies (affecting subsidiaries in some countries), cultural factors, factors contributing to the professionalization of management accounting practitioners (including the activities of international consulting companies) (Szychta, 2008, p. 209).

It should also be remembered that in the next phases of growth, small and mediumsized enterprises, due to the degree of maturity and their strategy of growth, use information gained through the use of tools of controlling and management accounting in different ways (Levy and Powell, 2005).

Taking into account the characteristics of the style of management, organizational culture and their own abilities, skills, knowledge and experience of entrepreneurs, one can try to simulate the application of selected tools to support decisionmaking in a growing company - they are presented in Table 4.

Undoubtedly, even the simplest tools of management accounting and controlling contribute to reducing business risk. Of course, the development of the management system, thanks to the growth of the company, may lead to wider use and implementation of advanced tools to support decision-making processes, including the identification and mitigation of negative effects of risk. The role of risk management systems in modern enterprises is undeniable (see e.g. Kaszuba-Perz and 
Table 4. Possible instruments of management accounting and controlling to support decision-making processes in a growing enterprise

\begin{tabular}{|c|c|c|c|c|c|}
\hline 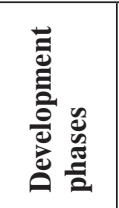 & $\begin{array}{c}\text { Phase } 1 \\
\text { Existence }\end{array}$ & $\begin{array}{l}\text { Phase } 2 \\
\text { Survival }\end{array}$ & $\begin{array}{c}\text { Phase } 3 \\
\text { Success: } \\
\text { - through } \\
\text { disengagement } \\
\text { - through growth }\end{array}$ & $\begin{array}{l}\text { Phase } 4 \\
\text { Take-off }\end{array}$ & $\begin{array}{l}\text { Phase } 5 \\
\text { Maturity }\end{array}$ \\
\hline 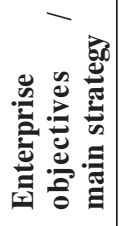 & Existence & Survival & $\begin{array}{l}\text { Maintaining advan- } \\
\text { tageous market } \\
\text { position and/or } \\
\text { looking for funds } \\
\text { supporting further } \\
\text { growth }\end{array}$ & Growth & Investing \\
\hline 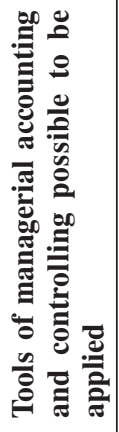 & $\begin{array}{l}\text { Simple prospec- } \\
\text { tive economic } \\
\text { accounts to } \\
\text { assess the eco- } \\
\text { nomic activi- } \\
\text { ties undertaken } \\
\text { on the basis of } \\
\text { forecast rev- } \\
\text { enues and costs. }\end{array}$ & $\begin{array}{l}\text { Simple prospective } \\
\text { and retrospective } \\
\text { economic accounts } \\
\text { to assess the business } \\
\text { with an assessment of } \\
\text { actions taken to stabi- } \\
\text { lize the operation of } \\
\text { the company (mainly } \\
\text { based on the analy- } \\
\text { sis of revenues and } \\
\text { expenses, and the cost } \\
\text { of capital employed). }\end{array}$ & $\begin{array}{l}\text { Prospective and } \\
\text { retrospective eco- } \\
\text { nomic analyses. } \\
\text { The forecast of } \\
\text { financial effects of } \\
\text { undertakings, tak- } \\
\text { ing into account } \\
\text { the time value of } \\
\text { money and rein- } \\
\text { vestment. }\end{array}$ & \multicolumn{2}{|c|}{$\begin{array}{l}\text { The use of complex finan- } \\
\text { cial and economic analy- } \\
\text { ses taking into account } \\
\text { the numerous areas of } \\
\text { company management. } \\
\text { Studying the connections } \\
\text { between information } \\
\text { channels, creating a new } \\
\text { network structure of the } \\
\text { information flow. The use } \\
\text { of integrated enterprise } \\
\text { management systems. }\end{array}$} \\
\hline
\end{tabular}

Source: the author's own study using the concept of company growth by: Churchill and Levis (1983).

Perz, 2010; Kimbrough and Componation, 2009). And more or less complex systems of collection, processing and presentation of data for management purposes contribute to obtaining better results in business.

\section{Barriers to and Opportunities} for the Use of Certain Controlling Tools for the Identification and Assessment of Risks in the Development Process of the Company

Businesses at the early stages of existence are reluctant to support professional instrumentation which allows for orderly identification and measurement of risks. Most often, based on their own experience and observation of the environment, they make an overall assessment of the situation and make decisions. If this applies to micro-enterprises, such an action seems justified as without the knowledge and skills to study the risks expenditure on an analysis would be too high. It also turns out that in real terms the confrontation with the local market in this situation is the best way to check the accuracy of decisions. However, such behavior cannot work well at later stages of company development because of an increasing amount of internal and external information affecting the functioning of the company. While a simple analysis of mainly qualitative nature would be sufficient in the phase of establishment and survival of the company, then in the next stages it should be completed at least by forecasts of economic calculus in several variants (optimistic, pessimistic, most likely). Of course, it will not always be possible (see Table 5).

From the very beginning of business activity, entrepreneurs are fully aware of the risks taken. Both in the first phase and in the phase of survival, they attempt to assess the scale of risks primarily based on their qualitative characteristics. Only in the subsequent stages of the company growth do they introduce elements of a more elaborate account which may include elements of risk (e.g. through the use of tools such as value of money in time, return rate, return 


\begin{tabular}{|c|c|c|c|c|c|}
\hline $\begin{array}{c}\text { Development } \\
\text { phases }\end{array}$ & $\begin{array}{c}\text { Phase } 1 \\
\text { Existence }\end{array}$ & $\begin{array}{l}\text { Phase } 2 \\
\text { Survival }\end{array}$ & $\begin{array}{c}\text { Phase } 3 \\
\text { Success: } \\
\text { - through disengagement } \\
\text { - through growth }\end{array}$ & $\begin{array}{l}\text { Phase } 4 \\
\text { Take-off }\end{array}$ & $\begin{array}{l}\text { Phase } 5 \\
\text { Maturity }\end{array}$ \\
\hline $\begin{array}{l}\text { Possibilities of } \\
\text { using controlling } \\
\text { tools, in particu- } \\
\text { lar those of risk } \\
\text { identification } \\
\text { and measure- } \\
\text { ment }\end{array}$ & $\begin{array}{l}\text { Only intuitive risk iden- } \\
\text { tification based on the } \\
\text { experiences of the own- } \\
\text { er-entrepreneur. }\end{array}$ & $\begin{array}{l}\text { Identification of risk } \\
\text { - intuitive based on } \\
\text { careful observation of } \\
\text { the environment by } \\
\text { the entrepreneur and } \\
\text { his closest associates. }\end{array}$ & $\begin{array}{l}\text { Analysis of the environment using } \\
\text { common tools known in the art of } \\
\text { management. By converting man- } \\
\text { agement style and the emergence } \\
\text { of new organizational structures, } \\
\text { possible risks may also be identified } \\
\text { at lower levels of management and } \\
\text { no longer based solely on experi- } \\
\text { ence and intuition of the entrepre- } \\
\text { neur-owner. Entities at this stage } \\
\text { of development are more likely to } \\
\text { reach for the help of experts and } \\
\text { external consulting firms. }\end{array}$ & $\begin{array}{l}\text { Comprehensive analy- } \\
\text { sis of the environment, } \\
\text { often with the use of } \\
\text { professional instru- } \\
\text { ments in the field of } \\
\text { management and con- } \\
\text { trolling. When making } \\
\text { important decisions, } \\
\text { a company uses exter- } \\
\text { nal experts or consult- } \\
\text { ing firms. Often, these } \\
\text { actions are combined } \\
\text { with a thorough staff } \\
\text { training. }\end{array}$ & $\begin{array}{l}\text { At this stage, together with } \\
\text { the investments related to } \\
\text { the implementation of new } \\
\text { technologies and ongoing } \\
\text { research and development } \\
\text { of new products, business- } \\
\text { es often implement proj- } \\
\text { ects related to the imple- } \\
\text { mentation of integrated } \\
\text { information management } \\
\text { systems, where one of the } \\
\text { modules is a subsystem of } \\
\text { risk management. }\end{array}$ \\
\hline $\begin{array}{l}\text { Barriers to the } \\
\text { use of tools to } \\
\text { identify and } \\
\text { measure risk }\end{array}$ & $\begin{array}{l}\text { Because Polish micro } \\
\text { and small enterprises use } \\
\text { simplified forms of taxa- } \\
\text { tion and thus simplified } \\
\text { bookkeeping, there is no } \\
\text { possibility of applying } \\
\text { mathematical and finan- } \\
\text { cial instruments support- } \\
\text { ing management in gen- } \\
\text { eral and risk assessment } \\
\text { in particular. }\end{array}$ & $\begin{array}{l}\text { Little or no possibili- } \\
\text { ties of applying con- } \\
\text { trolling instruments } \\
\text { mainly because own- } \\
\text { er-entrepreneurs fear } \\
\text { disclosure of company } \\
\text { information to exter- } \\
\text { nal experts who would } \\
\text { carry out adequate } \\
\text { economic analyses. }\end{array}$ & $\begin{array}{l}\text { Underdeveloped information sys- } \\
\text { tem (often not adapted to the size } \\
\text { of business) may result in incom- } \\
\text { plete risk identification and inad- } \\
\text { equate risk assessment. }\end{array}$ & \multicolumn{2}{|c|}{$\begin{array}{l}\text { Longer information flow through more formalized } \\
\text { and bureaucratic organizational structure; no direct } \\
\text { contacts of management staff with the environment; } \\
\text { exclusive receipt of already developed data needed } \\
\text { for decision-making can cause interference at the } \\
\text { level of identification of individual risks, or neglect } \\
\text { some of them. }\end{array}$} \\
\hline
\end{tabular}

Source: the author's own study based on the concept of company growth by: Churchil and Levis (1983). 
on reinvestment and course options with projections of revenues, costs, financial statements). We should be aware of the multiplicity of factors affecting the degree of implementation of controlling tools or financial maths in management processes. Certainly the intellectual capital and undoubtedly financial capacity are among the most important ones - especially when it comes to the implementation of integrated management systems in the stage of maturity. It is worth noting that the level of knowledge, skills and awareness of the need for risk measurement and willingness to look for tools to prevent its negative effects are very important from the point of view of the effectiveness of operational management as well as prospects for further development of the company.

\section{Conclusions}

Although risk identification and measurement are extremely difficult processes, one should not forget how important they are in the life cycle of the company, especially in times of the so-called breakthroughs. As a rule, small and mediumsized companies are considered to be highly flexible and willing to take risks; however, insufficient access to information and its poor quality and the underestimation of some internal and external factors that could cause such risks can lead to failure, resulting in even closure of activities. Small businesses base their decision-making processes primarily on experience and intuition of the owner - the entrepreneur. The tool of bookkeeping (simplified forms at the early stages of company life) is certainly an important factor limiting the provision of financial information for strategic decisions. The implementation of systems that support decision-making processes in the smallest businesses - undoubtedly entailing financial expenditure - would be disproportionate to the results achieved. However, with the growth of the company, in the next stages of its development, the information needs increase, organizational structures and management style evolve, conditions of the functioning of such a company change. Hence an undeniable need to identify and measure risk may seem one of the important aspects that should be included in the area of interest of owners and managers.

\section{Footnotes}

1 For specifying the group of micro, small and medium-sized enterprises, the accepted definition is that in accordance with the Law on Freedom of Economic Activity of 2 July 2004 in its new version since 18 January 2016 (JOL 2015 item 584). Describing controlling tools that support risk management, the author means the whole group of companies, in particular she refers in the article to the processes of their growth. These processes include the initiation phases of economic activity, and these are often associated with pursuing activity in the form of micro-enterprises. Only in the subsequent stages of development are these companies transformed into small and medium-sized companies.

2 A literature review and interesting characteristics and classification of risks in a company are offered by M. Thlon, Charakterystyka i klasyfikacja ryzyka $w$ działalności gospodarczej, Zeszyty Naukowe UEK, 2013; 902: pp. 17-36.

3 Risk management processes are often implemented as part of larger systems (e.g. information, controlling, or management accounting systems). These systems include a variety of techniques, instruments, tools, procedures for the collection, processing and presentation of information (data) for more efficient decisionmaking. Therefore, in this study, these terms are often used in a broad context and relate to the total number of instruments used in the enterprise for management purposes.

\section{References}

Adizes, I. (1988). Corporate Lifecycles. How and Why Corporations Grow and What to Do About It. Englewood Cliffs: Prentice-Hall.

Bober, P. and Chęciński, S. (2012). Kryzys gospodarczy a rozwój sektora małych i średnich przedsiębiorstw w Polsce. Zeszyty Naukowe Uniwersytetu Szczecińskiego, 690; Finanse, Rynki Finansowe, Ubezpieczenia, 51

Borowiecki, R. and Siuta-Tokarska, B. (2008). Problemy funkcjonowania matych $i$ średnich przedsiębiorstw w Polsce. Warszawa: Difin.

Cebrowska, T. (2010). Rachunkowość finansowa $i$ podatkowa. Warszawa: Wydawnictwo Naukowe PWN.

Chapman, R.J.(2011). Simple Tools and Techniques for Enterprise Risk Management. John Wiley \& Sons Ltd.

Churchil, N.C. and Levis, V.L. (1983). The five stages of small business growth. Harvard Business Review (May-June).

Damodaran, A. (2009). Ryzyko strategiczne. Warszawa: WAiP. 
Gościński, J.W. (1989). Cykl życia organizacji. Warszawa: PWE.

Grzybowski, W. (1995). Przedsiębiorczość, niepewność, zysk. Lublin: Wydawnictwo UMCS.

Hopkin, P. (2012). Fundamentals of Risk Management, $2^{\text {nd }}$ edition. Understanding, Evaluating and Implementing Effective Risk Management. The Institute of Risk Management.

Jajuga, K. (ed.) (2008). Zarzadzanie ryzykiem. Warszawa: Wydawnictwo Naukowe PWN.

Kaczmarek, T.T. (1999). Zarzadzanie ryzykiem handlowym i finansowym dla praktyków. Gdańsk: Ośrodek Doradztwa i Doskonalenia Kadr.

Kasiewicz, S. (ed.) (2011). Zarządzanie zintegrowanym ryzykiem przedsiębiorstwa w Polsce. Warszawa: Oficyna a Wolters Kluwer business.

Kaszuba-Perz, A. and Perz, P. (2008). Metody pomiaru ryzyka rynkowego w systemie controllingu. In: E. Nowak (ed.), Rachunkowość zarzadcza w warunkach globalizacji, Prace Naukowe Uniwersytetu Ekonomicznego we Wroctawiu no. 15. Wrocław.

Kaszuba-Perz, A. and Perz, P. (2010). Innowacyjne rozwiązania controllingowe w kontekście zarządzania przedsiębiorstwem w dobie kryzysów gospodarczych. In: M.G. Woźniak (ed.), Nierówności spoteczne a wzrost gospodarczy, Zeszyty Naukowe UR no. 17. Rzeszów.

Kaszuba-Perz, A. and Perz, P. (2010). Rola zarządzania ryzykiem $\mathrm{w}$ przedsiębiorstwie $\mathrm{w}$ obliczu wzrostu zewnętrznych czynników ryzyka. $e$-Finanse - Finansowy Kwartalnik Internetowy, 6(2).

Kimbrough, R.L. and Componation, P.J. (2009) The Relationship Between Organizational Culture and Enterprise Risk Management. Engineering Management Journal, 21.

Knight, F. (1921). Risk, Uncertainty and Profit. London: University of London.

Knight, E.H. (2005). Risk, Uncertainty and profit. New York: Cosimo Classics.

Kochamńska, M. (2007). Bariery rozwoju przedsiębiorczości małych i średnich firm. Zeszyty Naukowe, 1. Sosnowiec: Wydawnictwo Wyższej Szkoły Humanitas.

Kozień, E. (1999). Przedsiębiorczość w rozwoju przedsiębiorstw. In: J. Targalski (ed.), Przedsiębiorczość a lokalny i regionalny rozwój gospodarczy. Kraków: Wydawnictwo AE w Krakowie.

Koźmiński, A.K. (2004). Zarzadzanie w warunkach niepewności. Warszawa: Wydawnictwo Naukowe PWN.
Koźmiński, A.K. (2012). Zarzqdzanie w warunkach niepewności. Podręcznik dla zaawansowanych. Warszawa: Wydawnictwo Naukowe PWN.

Levy, M. and Powell, P. (2005). Strategies for Growth in SMEs: The Role of Information and Information Systems. Oxford: Elsevier Butterworth-Heinemann.

Matejun, M. and Motyka, A. (2015). Dynamika barier w cyklu życia firm sektora MSP - wyniki badań monograficznych. Marketing i Rynek, 5, 665-683.

Nowak E. (ed.) (2010). Rachunkowość w zarzadzaniu ryzykiem $w$ przedsiębiorstwie. Warszawa: Polskie Wydawnictwo Ekonomiczne.

Olszewska, B. (2010). Czynniki zmian przełomowych w przedsiębiorstwie. Studia i Prace Kolegium Zarzadzania i Finansów, Zeszyt Naukowy no. 100. Szkoła Główna Handlowa w Warszawie.

Ostrowska, E. (2002). Ryzyko projektów inwestycyjnych. Warszawa: PWE

Pasieczny, L. (1981). Encyklopedia organizacji i zarzadzania. Warszawa: PWE.

Rogowski, W. and Michalczewski, A. (2005). Zarzadzanie ryzykiem $w$ przedsięwzięciach inwestycyjnych. Kraków: Oficyna Ekonomiczna.

Roth, G. and Kurtyka, M. (2008). Zarzadzanie zmiana. Od strategii do działania. Warszawa: CeDeWu Sp. z o.o.

Sysko-Romańczuk, S. and Platonoff, A.L. (2003) Dynamiczne modelowanie funkcjonowania przedsiębiorstwa. Organizacja i Kierowanie, 2.

Sysko-Romańczuk, S. (2005). Rozwój przedsiębiorstwa jako rezultat jego wzrostu i sprawności procesów zarzadzania. Szczecin: Wydawnictwo Naukowe Uniwersytetu Szczecińskiego.

Szychta, A. (2008). Etapy ewolucji i kierunki integracji metod rachunkowości zarzadczej. Łódź: Wydawnictwo Uniwersytetu Lódzkiego.

Wierzbińska, M. (1996). Ryzyko $w$ gospodarce rynkowej $w$ okresie transformacji systemowej. Lublin: Wydawnictwo Uniwersytetu Marii Curie-Skłodowskiej.

Varvari, T. (2015). Risk, Risk Perception, Risk Management - a Review of the Literature. Public Finance Quarterly, 1.

Quinn, R.E. and Cameron, K. (1983). Organizational Life Cycle and Shifting Criteria of Effectiveness: Some Preliminary Evidence. Management Science, 29.

Werheugen, G. (2005). The new SME definition. User guide and model declaration. Brussels, Belgium: European Commission. 